\title{
STRATEGI BELAJAR AKTIF TIPE EVERYONE IS A TEACHER HERE (ETH) TERHADAP HASIL BELAJAR SISWA KELAS XI IA SMAN 5 SOLOK SELATAN
}

\section{ACTIVE LEARNING STRATEGY ON TYPE EVERYONE IS A TEACHER HERE (ETH) TO LEARNING OUTCOMES OF CLASS XI IA SMAN 5 SOLOK SELATAN}

\author{
Ruth RizePaas Megahati S \\ Program Studi Pendidikan Biologi STKIP PGRI Sumatera Barat \\ Jl. Gunung Pangilun Padang, Kota Padang, Sumatera Barat, Indonesia. \\ Telp./Fax. (0751)7053731/ (0751) 7053826. Email: megahati@gmail.com \\ Manuskript diterima : 4 Oktober 2016. Revisi disetuji 15 November 2016
}

\section{ABSTRACT}

Biology student learning outcomes is still low due to a lack of understanding and mastery of the subject matter on the subjects of the system of coordination and students tend to participate less in passive and learning. One strategy that can improve student learning outcomes is the type of active learning strategies Everyone is a Teacher Here (ETH). This research is experimental research design Randomized Control Group Posttest Only Design. The population in this study were all students of class XI SMAN 5 IA Solok Selatan. The sample in this research is class XI IA1 as an experimental class and class XI IA2 as the control class. The purpose of this study was to determine the effect of type of active learning strategies Everyone is a Teacher Here (ETH) to the learning outcomes biology class XI student of SMAN 5 IA Solok Selatan. The results showed that the students' learning outcomes biology experimental class is higher than the control class. This means that the hypothesis is accepted. It can be concluded biology student learning outcomes in learning to use active learning strategies type Everyone is a Teacher Here is better than conventional learning.

Keywords : Learning outcome, ETH, active learning strategies, biology learning

\section{ABSTRAK}

Rendahnya hasil belajar biologi siswa karena kurangnya pemahaman dan penguasaan materi pelajaran pada topik sistem koordinasi dan siswa cendrung pasif dan kurang berpartisipasi dalam belajar. Salah satu strategi yang dapat meningkatkan hasil belajar siswa adalah dengan strategi belajar aktif tipe Everyone is a Teacher Here (ETH). Penelitian ini merupakan penelitian eksperimen dengan rancangan penelitian Randomized Control Group Postest Only Design. Populasi dalam penelitian ini adalah seluruh siswa kelas XI IA SMAN 5 Solok Selatan. Sampel dalam penelitian ini adalah kelas XI IA ${ }_{1}$ sebagai kelas eksperimen dan kelas XI $\mathrm{IA}_{2}$ sebagai kelas kontrol. Tujuan dari penelitian ini adalah untuk mengetahui pengaruh strategi belajar aktif tipe Everyone is a 
Teacher Here (ETH) terhadap hasil belajar biologi siswa kelas XI IA SMAN 5 Solok Selatan. Hasil penelitian menunjukkan bahwa hasil belajar biologi siswa kelas eksperimen lebih tinggi daripada kelas kontrol. Hal ini dapat disimpulkan hasil belajar biologi siswa yang dalam pembelajarannya menggunakan strategi belajar aktif tipe Everyone is a Teacher Here lebih baik dibandingkan dengan pembelajaran konvensional.

Kata kunci: Hasil belajar, ETH, strategi belajar aktif, belajar biologi

\section{PENDAHULUAN}

Pembelajaran yang kondusif penuh interaksi timbal balik sangat didambakan oleh setiap pihak pada lingkungan pendidikan khususnya di dalam pembelajaran Biologi. Biologi merupakan suatu ilmu yang mengkaji tentang makhluk hidup mulai dari yang sederhana sampai ke yang kompleks. Guru sebagai seorang pendidik harus mampu menggunakan strategi yang tepat dalam proses pembelajaran. Dengan strategi yang digunakan di dalam pembelajaran dapat mengubah hasil belajar siswa sehingga memperlihatkan hasil yang memuaskan. Realitanya masih banyak siswa yang mendapatkan nilai rendah.

Rendahnya hasil belajar Biologi siswa juga terjadi di SMAN 5 Solok Selatan, hal ini masih terlihat banyaknya nilai Biologi siswa kelas XI IA yang masih rendah. Perolehan data dari guru Biologi SMAN 5 Solok Selatan nilai ratarata ulangan harian siswa pada materi sistem koordinasi kelas XI IA tahun pelajaran 2010/2011 adalah sebagai berikut: XI IA $1(67,1)$ siswa yang tidak tuntas 18 dari 30 siswa, XI IA $2(65,68)$ siswa yang tidak tuntas 23 dari 34 siswa, XI IA 3 $(67,06)$ siswa yang tidak tuntas 22 dari 32 siswa. Berdasarkan hasil observasi dan wawancara serta data yang diperoleh dari salah satu guru Biologi siswa kelas XI IA SMAN 5 Solok Selatan bahwa nilai siswa di bawah kriteria ketuntasan minimal (KKM). KKM mata pelajaran Biologi di sekolah ini adalah 70. Beberapa faktor yang menyebabkan rendahnya hasil belajar Biologi diantaranya kesulitan yang 
dihadapi siswa yaitu pemahaman dan penguasaan materi pelajaran. Jika diadakan kerja kelompok, hanya beberapa orang yang berpartisipasi sementara siswa yang lain hanya berdiam diri dan mengandalkan siswa yang pandai, selain itu siswa juga kurang bertanggung jawab terhadap tugas yang diberikan guru. Pada akhirnya pola pembelajaran siswa lebih bersifat menghafal. Ini mengakibatkan materi pelajaran yang diterima kurang dipahami dan cepat hilang dari ingatan siswa bahkan siswa cenderung melupakannya, sehingga mempengaruhi hasil belajar siswa dalam belajar Biologi.

Upaya yang dapat dilakukan untuk meningkatkan aktivitas belajar siswa yaitu dengan menerapkan strategi belajar aktif. Menurut Silberman (2006:171) strategi belajar aktif terdiri atas beberapa tipe salah satu diantaranya yaitu Everyone is a Teacher Here (ETH). Untuk mencapai hasil belajar yang lebih baik maka penulis telah meneliti pengaruh strategi belajar aktif tipe ETH. ETH berarti siswa dapat bertindak sebagai guru. Siswa menjelaskan suatu konsep atau memberi penjelasan atas pertanyaan di depan kelas sehingga siswa lain dapat menangkap maksud atau idenya. Tujuan dari penelitian ini adalah untuk mengetahui pengaruh penerapan strategi belajar aktif tipe everyone is a teacher here terhadap hasil belajar Biologi siswa kelas XI IA SMAN 5 Solok Selatan.

Berdasarkan uraian di atas, penulis telah melakukan penelitian tentang "Pengaruh penerapan strategi belajar aktif tipe Everyone is a Teacher Here (ETH) terhadap hasil belajar Biologi siswa kelas XI IA SMAN 5 Solok Selatan “.

\section{METODE PENELITIAN}

Rancangan penelitian yang digunakan dalam penelitian ini adala Randomized Control Group Postest Only Design. Penelitian ini dilaksanakan di kelas XI IA pada SMAN 5 Solok Selatan. Populasi dalam penelitian ini adalah seluruh siswa kelas XI IA SMAN 5 Solok Selatan yang terdiri dari dua kelas. Dimana pengambilan sampel dilakukan secara undian yang hasilnya kelas XI IA 1 sebagai kelas eksperimen dan kelas XI IA 2 sebagai kelas kontrol.

Prosedur penelitian ini terdiri dari tahap persiapan, tahap pelaksanaan dan tahan penyelesaian. Instrumen penelitian ini adalah tes hasil belajar berbentuk pilihan ganda dengan melakukan validitas soal, reliabilitas soal, daya pembeda soal dan indeks kesukaran. Soal merujuk pada Arikunto (2009: 208). Analisis 
data penelitian dilakukan bertujuan untuk menguji kebenaran hipotesis yang diajukan dalam penelitian. Teknik analisis data yang digunakan dalam penelitian ini adalah uji-t, sebelum uji hipotesis dilakukan uji normalitas dan homogenitas variens kedua sampel merujuk pada Sudjana (2005: 249).

\section{HASIL}

$\underline{\text { Tabel 1. Nilai Rata-rata, Simpangan Baku, Varians Kelas Eksperimen dan Kelas Kontrol }}$

\begin{tabular}{lcccc}
\hline \multicolumn{1}{c}{ Kelas } & $\mathrm{N}$ & $\bar{X}$ & $\mathrm{~S}$ & $\mathrm{~S}^{2}$ \\
\hline Eksperimen & 35 & 71,11 & 13,42 & 180,26 \\
\hline Kontrol & 36 & 61,57 & 15,25 & 232,52 \\
\hline
\end{tabular}

Tabel 2. Hasil Uji Normalitas Kelas Eksperimen dan Kelas Kontrol

\begin{tabular}{lccccc}
\hline \multicolumn{1}{c}{ Kelas } & $\mathrm{N}$ & $\mathrm{A}$ & $\mathrm{L}_{\mathrm{o}}$ & \multicolumn{1}{c}{$\mathrm{L}_{\mathrm{t}}$} & Kriteria \\
\hline Eksperimen & 35 & 0,05 & 0,1028 & 0,14991 & Normal \\
\hline Kontrol & 36 & 0,05 & 0,1015 & 0,1476 & Normal \\
\hline
\end{tabular}

Tabel 3. Hasil Uji Homogenitas Kelas Eksperimen dan Kelas Kontrol

\begin{tabular}{|c|c|c|c|c|c|c|c|c|}
\hline Kelas & & $\mathrm{N}$ & $\bar{X}$ & $S$ & $\mathrm{~S}^{2}$ & $\begin{array}{c}F_{\text {hitun }} \\
\mathrm{g}\end{array}$ & $\begin{array}{c}\mathrm{F}_{\mathrm{tab}} \\
\mathrm{el}\end{array}$ & Kriteria \\
\hline Eksperimen & & 35 & 71,11 & 13,42 & $\begin{array}{c}180,2 \\
6\end{array}$ & 0,77 & $\begin{array}{c}2,2 \\
0\end{array}$ & Homogen \\
\hline Kontrol & & 36 & 61,57 & 15,25 & $\begin{array}{c}232,5 \\
2\end{array}$ & 0,77 & $\begin{array}{c}2,2 \\
0\end{array}$ & Homogen \\
\hline Kelas & $t_{\text {hitung }}$ & $\mathrm{t}_{\text {tabel }}$ & \multicolumn{4}{|c|}{ Kesimpulan } & & \\
\hline $\begin{array}{l}\text { Eksperimen } \\
\text { kontrol }\end{array}$ & 2,76 & 1,67 & \multicolumn{3}{|c|}{$\mathrm{H}_{1}$ diterima } & & & \\
\hline
\end{tabular}

\section{PEMBAHASAN}

Berdasarkan kegiatan penelitian yang dilakukan, dapat penulis lihat perbedaan antara siswa yang menggunakan strategi belajar aktif tipe Everyone is a Teacher Here (ETH) lebih baik hasil belajarnya daripada hasil belajar Biologi siswa yang menggunakan pembelajaran konvensional. Dari analisis data yang diperoleh nilai rata-rata tes akhir kelas eksperimen $=71,11$ dan kelas kontrol $=$ 61,57. Dari nilai rata-rata tes akhir tesebut jelas terlihat bahwa adanya peningkatan hasil belajar siswa kelas eksperimen dibandingkan dengan kelas kontrol.

Dalam penelitian ini yang hipotesisnya diterima menunjukkan bahwa perbedaan hasil belajar Biologi kedua kelas sampel signifikan pada taraf 0,05. 
Perbedaan ini terjadi karena adanya pengaruh terhadap perlakuan yang diberikan kepada kelas eksperimen dengan strategi belajar aktif tipe ETH.

Berdasarkan pengamatan penulis selama melakukan penelitian terlihat bahwa siswa kelas eksperimen lebih senang dan bersemangat dalam proses pembelajaran. Hal ini dapat dilihat pada saat penelitian yaitu setiap siswa diberikan handout sebelum pembelajaran berikutnya dan siswa diminta untuk membaca dan memahami handout tersebut sehingga pada saat proses pembelajaran siswa akan mudah untuk membuat suatu pertanyaan berdasarkan handout tersebut kedalam kartu indeks. Siswa akan berusaha membuat sebuah pertanyaan yang tidak dimengerti sehingga siswa yang selama ini tidak aktif akan menjadi aktif dalam proses pembelajaran. Setelah itu kartu indeks dikumpul dan dikocok kemudian dikembalikan lagi kepada siswa yang berbeda untuk meminta jawaban atas pertanyaan yang mereka dapat di depan kelas. Hal ini juga sesuai dengan penelitian Misnar (2011) yang mengatakan bahwa " dalam proses pembelajaran menggunakan strategi belajar aktif tipe ETH siswa dituntut untuk berfikir kritis, menemukan suatu masalah dan mencari pemecahan disetiap permasalahan yang mereka temukan".

Menurut Bruner (1973) dalam Lufri (2007:14) “ belajar melibatkan tiga proses yang berlangsung hampir bersamaan, yaitu : (1) memperoleh informasi baru, (2) transformasi informasi, dan (3) menguji relevansi dan ketepatan pengetahuan".

Dari uraian di atas maka dapat disimpulkan bahwa strategi pembelajaran aktif tipe ETH memberikan pengaruh terhadap hasil belajar siswa. Hal ini terbukti dari hasil tes yang diberikan dimana kelas eksperimen memperoleh nilai rata-rata yang lebih tinggi dibandingkan dengan kelas kontrol. Dengan demikian pembelajaran aktif tipe ETH telah dibuktikan secara statistik dapat menjawab permasalahan dalam penelitian ini, sehingga hipotesisnya dapat diterima.

\section{SIMPULAN}

Berdasarkan hasil penelitian yang telah dilakukan maka dapat disimpulkan bahwa strategi belajar aktif tipe ETH berpengaruh positif terhadap hasil belajar Biologi siswa kelas XI IA SMAN 5 Solok Selatan, dimana hasil belajar Biologi 
yang menggunakan strategi belajar aktif tipe ETH lebih baik dibandingkan dengan hasil belajar Biologi yang menggunakan pembelajaran konvensional.

\section{SARAN}

Dari hasil penelitian yang diperoleh, penulis mengemukakan beberapa saran yang sekiranya dapat memberikan masukan guna peningkatan hasil belajar biologi yaitu:

1. Untuk meningkatkan hasil belajar, penulis mengharapkan kepada guru Biologi untuk dapat menggunakan strategi pembelajaran aktif tipe ETH sebagai salah satu upaya dalam menciptakan variasi-variasi dalam proses belajar mengajar.

2. Penulis mengharapkan kepada peneliti selanjutnya dapat menerapkan strategi pembelajaran aktif tipe ETH pada materi yang berbeda.

\section{DAFTAR PUSTAKA}

Lufri. 2007. Kiat Memahami Metodologi dan Melakukan Penelitian. UNP Pres: Padang.

Lufri, dkk. 2007. Strategi Pembelajaran Biologi. UNP: Padang.

Misnar. 2011. Perbandingan Hasil Belajar Biologi Siswa dengan Menggunakan Strategi Everyone Is A Teacher Here (ETH) dan Strategi Listener Team Pada Siswa Kelas VIII SMPN 03 Koto Baru. Skripsi STKIP PGRI: Padang.

Silberman, Melvin . 2006. Active Learning 101 Strategi Pembelajaran Aktif.

Nusamedia: Bandung.

Sudjana. 2005. Metode Statistika. Tarsito: Bandung.

Suharsimi, Arikunto. 2009. Dasar-dasar Evaluasi Pendidikan. Rev.Bumi Aksara: Jakarta. 